\title{
EXPERIENCE WITH THE USE OF WARM MIX ASPHALT ADDITIVES IN BITUMEN BINDERS
}

\author{
Silvia CÁPAYOVÁ ${ }^{*}$, Stanislav UNČÍK ${ }^{1}$ Denisa CIHLÁŘOVÁ ${ }^{2}$
}

\section{Abstract}

In most European countries, Hot Mix Asphalt (HMA) technology is still being used as the standard for the production and processing of bituminous mixtures. However, from the perspective of environmental acceptability, global warming and greenhouse gas production, Slovakia is making an effort to put into practice modern technology, which is characterized by lower energy consumption and reducing negative impacts on the environment. Warm mix asphalt technologies (WMA), which have been verified at the Department of Transportation Engineering laboratory, Faculty of Civil Engineering, Slovak University of Technology (FCE, SUT) can provide the required mixture properties and can be used not only for the construction of new roads, but also for their renovation and reconstruction.

The paper was created in cooperation with the Technical University of Ostrava, Czech Republic, which also deals with the addition of additives to asphalt mixtures and binders. It describes a comparison of the impact of some organic and chemical additives on the properties of commonly used bitumen binders in accordance with valid standards and technical regulations.
Address

1 Faculty of Civil Engineering, Slovak University of Technology in Bratislava, Slovak Republic

2 Faculty of Civil Engineering, VŠB - Technical University of Ostrava, Czech Republic

* Corresponding author: silvia.capayova@stuba.sk

\section{Key words}

- Environmentally acceptable technologies

- Bitumen binders,

- Warm mix asphalt,

- Additives

- Penetration,

- Softening point.

\section{INTRODUCTION}

As mentioned above, in Slovakia, as well as in most other countries, HMA is still the most widely used technology for the production and processing of asphalt. It is a standard technology used for years. In 2015, the total production of hot and warm mix asphalt in Slovakia was 2.7 million tons, which represents a year-on-year increase of $80 \%$. However, warm mix asphalt (produced at 100-150 ${ }^{\circ} \mathrm{C}$ ) does not even make up one percent of this total amount. One of the most serious HMA negatives is its energy intensity and the production of greenhouse gases (GHG). In the production and processing of HMA, mainly PM-10 and PM-2.5 pollutants, hazardous atmospheric and metallic air pollutants (HAP), gaseous $\mathrm{NO}_{x}, \mathrm{CO}$, $\mathrm{CO}_{2}, \mathrm{SO}_{2}$ and VOC are realised; they cause vapours and result in high temperatures that affect the environment and workers. It is therefore obvious that the asphalt industry needs to reduce possible negative impacts and put into practice a standard production technology and processing at lower temperatures that would still ensure the desired properties of the mixture. In Slovakia, cold and lower temperature technologies for producing and processing the mixture are applied, but only in small quantities compared to HMA. The research suggests that with the use of cold technology, it is not possible to provide a long-term performance comparable to HMA. Therefore, it is more likely that the realistic replacement of the conventional technology is low-temperature asphalt mixtures (warm mix asphalt or half-warm mix asphalt).

According to the statistics for 2014 (European commision, 2016), transport accounts for about $23 \%$ (1026.2 million tons of $\mathrm{CO}_{2}$ ) of the 
total EU-28 greenhouse gas production; about $73 \%$ is road transport. The energy industry produces about $28 \%$. In Slovakia, road transport accounts for almost $94 \%$ of GHG production. The total energy consumption in the EU-28 was 1061.7 Mtoe with a 33\% traffic share (road transport: 82\%). In Slovakia, transport accounts for approximately $21 \%$ of the total energy consumption (road transport up to $90 \%)$.

\section{PRACTICAL EXPERIENCE}

In recent years, the Department of Transport Engineering, FCE, SUT, has focused on issues of the environmental acceptability of materials and technologies in road construction. Within the framework of national and international conferences and journals, we have presented the results of these projects, including this paper. Over the last period, the projects were primarily ITMS: 26240220084: University Science Park Slovak University of Technology in Bratislava, VEGA No. 1/0401/10 "Energy saving, economic and environmental roads and traffic platforms", and VEGA No. 1/0351/13 "Traffic area structures in integrated transport space". In 2010, closer cooperation with the Czech Technical University in Prague was renewed that focused on low-temperature asphalt mixtures and additives, the recycling and reuse of materials, and empirical and functional testing. Several sub-projects (Stefunkova, 2011) and their final reports were produced as a result of this cooperation, the results of which were presented in contributions, e.g., (Capayova et al. 2015), (Capayova et al., 2017). Additionally, there was a project under the Program to Support Young Researchers provided by the Slovak University of Technology in Bratislava; i.e., the WAM-DEF project "Deformation Properties of Warm Mix Asphalt", which was implemented in 2013. In general, attention has been focused on verifying the properties of paving grade and polymer modified bitumen binders, which are commonly used in road construction in Slovakia as well as the Czech Republic. They have mainly been 50/70 and 35/50 standard binders, which have been modified by various types of organic wax-based additives or modified by chemical additives, etc.

For the period 2017-2019, the Department has a funded VEGA Project No. 1/0501/17 "Environmentally acceptable materials and technologies for traffic areas", with the following main scientific objectives:

- administration of environmentally acceptable technologies with the aim of fulfilling Slovak and EU requirements for decreasing the production of emissions,

- the analysis of new energy-saving technologies compared with the traditional standardized technologies used,

- dissemination of knowledge about the use of new additives and, eventually, recycled materials for composite mixtures with respect to the operational ability of traffic areas,

- laboratory testing of the allowance of the determined strength and deformation properties of pavement structure mixtures for the calculated parameters of road building materials.

In the first year of the project's solution, it was already possible to at least verify the empirical properties of bitumen binder modified by Cecabase and Iterlow and by the organic ingredients Sasobit and Sasobit REDUX. For the solution of the project, cooperation with universities in the Czech Republic was considered as they have a great deal of experience in this area with different organic and chemical additives (Valentin at. al., 2014), for example, Cecabase (Hamzah at al., 2014), or adhesion promoters and the ageing of bitumen binder (Valentova at. al., 2016). In addition, efforts are also being made to work closely with Slovak universities. The addition of special additives to bitumen binders is also provided by specialists at the Faculty of Civil Engineering of the University of Žilina; e.g. in (Remisova at al., 2016), they presented the results of the effect of various additives on the empirical and functional properties of binders and mixes, their rheological properties, the impact of changes in temperature, etc. It is important to accurately simulate the actual behaviour of materials in a real environment, but the necessary equipment is very costly. Therefore, cooperation between various research institutes is necessary.

\subsection{The Use of Additives}

Additives for bitumen binders and mixtures are used in order to adjust or improve their properties. Since bitumen binders are characterized by their temperature sensitivity, one of the main objectives of using additives is the extension of the temperature range of their applicability. Another objective is to affect the viscosity of the binder, which is low at very high temperatures and high at low temperatures. The workability of an asphalt mixture depends on its viscosity. With the use of appropriate additives, we can adjust the bitumen grade, penetration, softening point, viscosity, etc., and subsequently positively affect the behaviour of the mixture at different temperatures and from different loads. In this case, we are mainly talking about organic additives.

We are also interested in chemical additives that work on the principle of a surfactant without affecting the bitumen grade to improve the adhesion between a binder and aggregates. As the traffic load steadily increases, the main requirement is that the asphalt mixtures used achieve the necessary strength and deformation characteristics, durability and fatigue.

As confirmed by much practical experience, chemical additives are shown to be most effective when used as a modifier of bitumen binders and mixtures, in terms of their influence on strength and deformation characteristics as well as the simplicity of their use. Some sources say even their economic efficiency is very dependent on the particular additive used. Certain additives, despite their excellent effect on the properties of a binder and the mixture, cannot be used precisely because of their cost, which makes the mixture produced too expensive. The problem with chemical additives is their environmental impact. Many of the additives are characterized, for example, by unpleasant odours that are harmful to workers. Some companies have therefore begun to produce low or no odour additives. They have also responded to the reduction of greenhouse gases, energy production, and the biodegradation of additives.

There are many additives on the market, mainly abroad, that are both new and already applied. For laboratory verifications, some organic and chemical additives were selected to modify reference binders with grades $35 / 50$ and 50/70.

\section{Organic additives:}

a. Sasobit - Synthetic Fischer-Tropsch paraffin wax without sulphur and other impurities. The additive influences the bitumen grade, stiffness and deformation characteristics of the asphalt mixture; extending the mixture's workability can reduce the temperature of the production, especially during laying of the mixture. Crystallization of the additive begins at $90^{\circ} \mathrm{C}$.

b. Sasobit REDUX contains synthetic Fischer-Tropsch wax and other oily waxes. It does not affect the binder grade and adhesion between the bitumen and aggregate, but it affects its viscosity and susceptibility to aging. It only influences the properties of the asphalt mixture with the required parameters, even at a lower temperature. The additive begins to crystallize at $60^{\circ} \mathrm{C}$. 


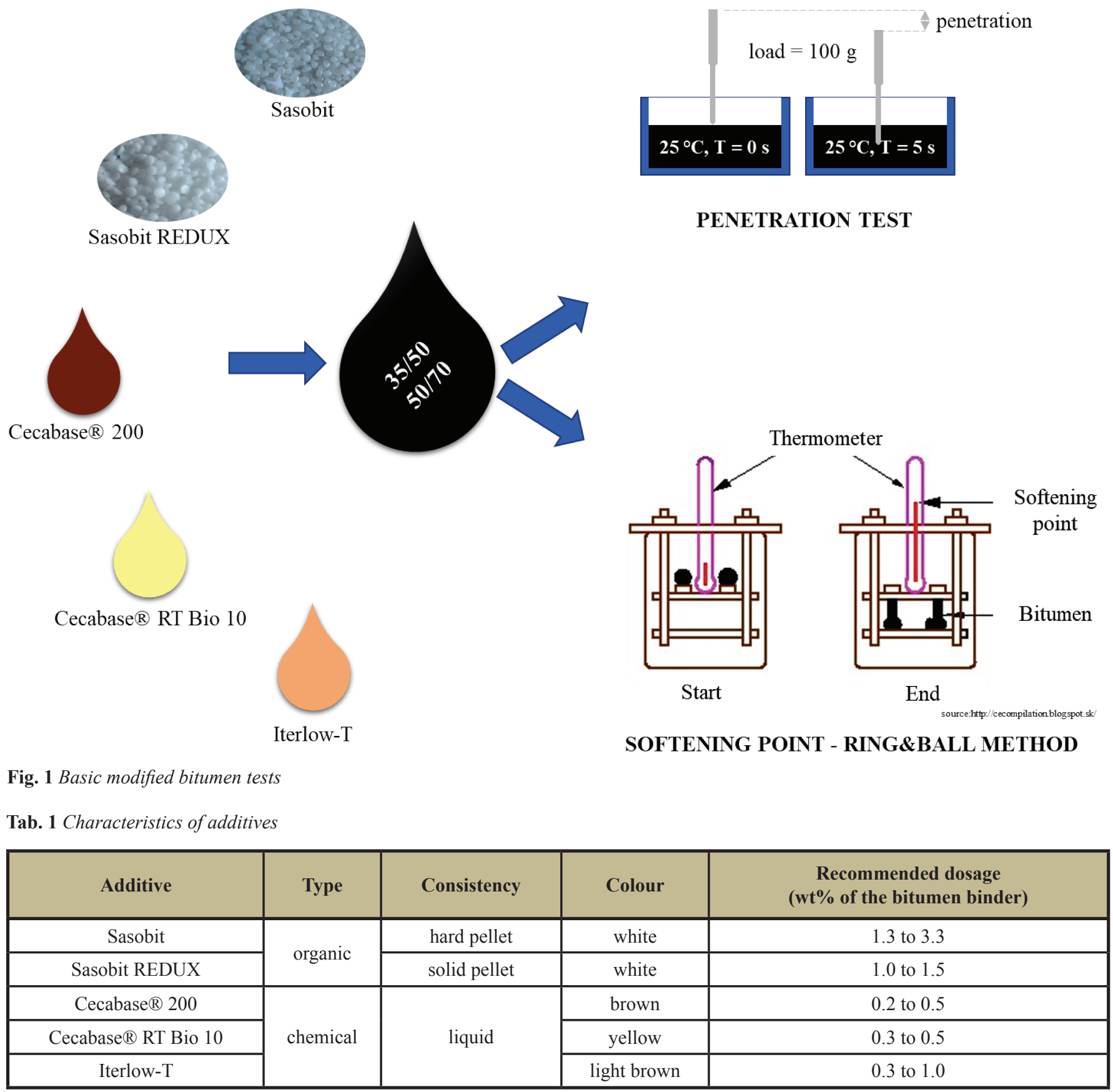

Tab. 2 Selected dosage of additives

\begin{tabular}{|c|c|c|}
\hline Asphalt & Additive & $\begin{array}{c}\text { Selected dosage } \\
\text { (wt\% of the bitumen binder) }\end{array}$ \\
\hline \multirow{4}{*}{$50 / 70(\mathrm{OMV})(1)$} & Sasobit & 2.5 \\
\hline & Sasobit REDUX & 1.5 \\
\hline & Cecabase ${ }^{\circledR} 200$ & 0.2 and 0.5 \\
\hline & Cecabase ${ }^{\circledR}$ RT Bio 10 & 0.5 \\
\hline 50/70 (OMV) (2) & Iterlow-T & 1.0 \\
\hline \multirow{4}{*}{ 35/50 (Orlen) } & Sasobit & 2.5 \\
\hline & Sasobit REDUX & 1.5 \\
\hline & Cecabase ${ }^{\circledR} 200$ & 0.5 \\
\hline & Cecabase ${ }^{\circledR}$ RT Bio 10 & 0.5 \\
\hline
\end{tabular}




\section{Chemical additives:}

a. Cecabase ${ }^{\circledR} \mathbf{2 0 0}$ additive has a melting point at $-11^{\circ} \mathrm{C}$ and a flash point higher than $100^{\circ} \mathrm{C}$. This asphalt additive for hot mix asphalt improves the adhesion between a binder and aggregates. The storage use is 7 days at $160^{\circ} \mathrm{C}$.

b. Cecabase ${ }^{\circledR}$ RT BIO 10 additive improves the workability of asphalt mixtures, with no change in the bitumen grade. Producing and paving with these mixtures can be at lower temperatures than the standard hot mix asphalt. The main environmental benefits when using the additive are the application of a higher amount of RAP, but less of an odour, fumes, and GHG emissions. The additive is biodegradable. The storage use is a minimum 7 days at $160{ }^{\circ} \mathrm{C}$.

c. Iterlow-T additive is composed of amino substance derivatives. Similarly, as with the previous additive, the main benefits are the better workability of a mixture, the ability to produce and pave the mixture at a lower temperature (between $90-120^{\circ} \mathrm{C}$, depending on the type of bitumen), and environmental benefits. Iterlow does not modify the bitumen grade. The flash point of the additive is more than $200{ }^{\circ} \mathrm{C}$.

We already have some experience in Slovakia with additives based on waxes such as Sasobit. Cecabase additives have already been applied and verified in France, Poland, and North America. There is not much interest in these additives in Slovakia. According to information from the producer's representative, this is mainly due to their price of approximately 5 Euro per $1 \mathrm{~kg}$ of additive. In addition to the prices, there is a requirement for some Cecabase additives to use only certain type of aggregates in the asphalt mixture. Except for the application of additives, the technology of foaming binders and natural and synthetic zeolites has also been tested in our country.

\subsection{Laboratory Verifications of Modified Bitumen binders}

The valid standards and technical regulations prescribe the declaration of the basic empirical properties of a binder, i.e., a penetration test according to STN EN 1426 (2016) and determination of the softening point according to STN EN 1427 (2016) (Figure 1).

As can be seen from the characterization of the ingredients used in Section 1, only the Sasobit additive should affect the bitumen grade. This was verified in 2009 and 2010 when we first used the additive to modify the properties of the binder and mixture. The additive was in a powder form in dosages of 1,2 and $3 \%$ of the total amount of 50/70 bitumen. The results presented in (Capayova at. al., 2017) show that the wax caused a decrease in penetration, an increase in the softening point and had no effect on the Fraas breaking point. We have now reverified the properties of the 50/70 paving grade, which was modified by Sasobit in the form of small pellets in a dosage of $2.5 \%$ of the binder.

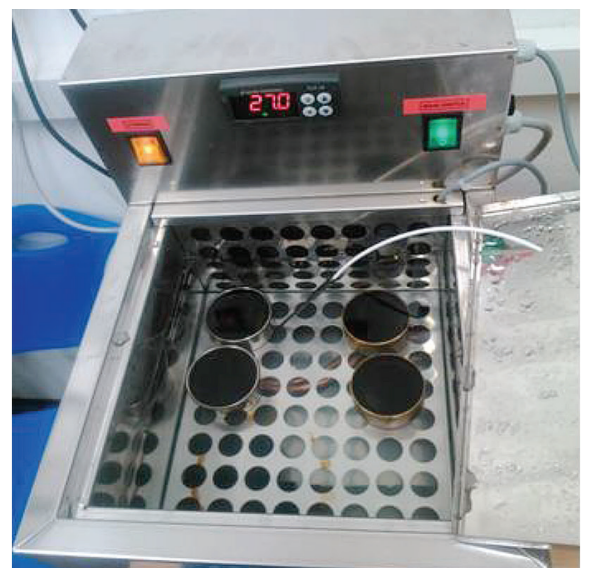

a) tempering of samples

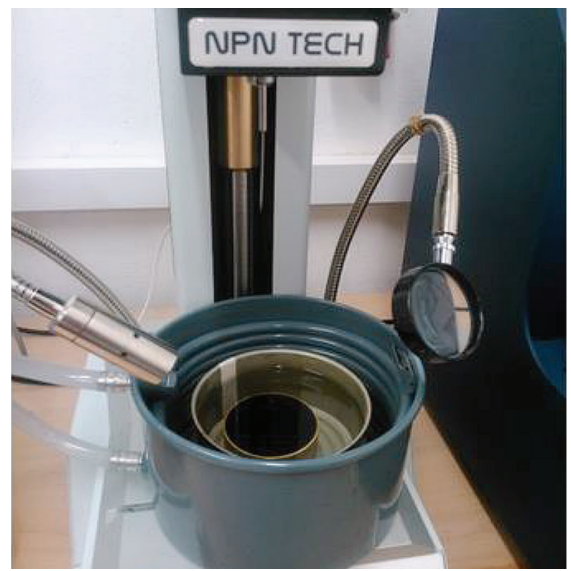

b) configuration of the laboratory test

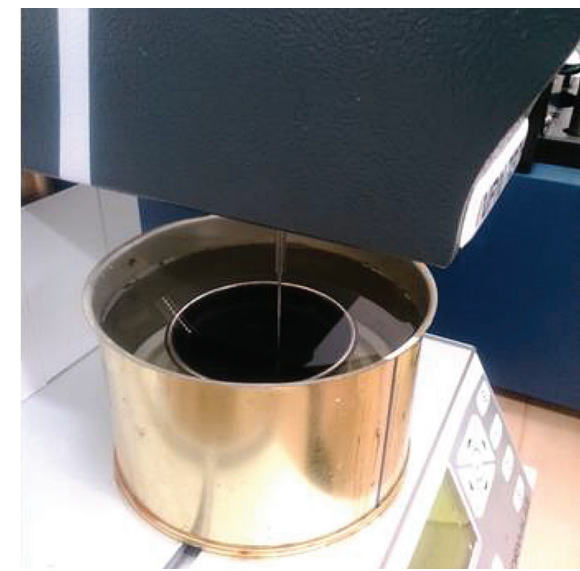

c) measuring under water

Fig. 2 Penetration tests according to STN EN 1426

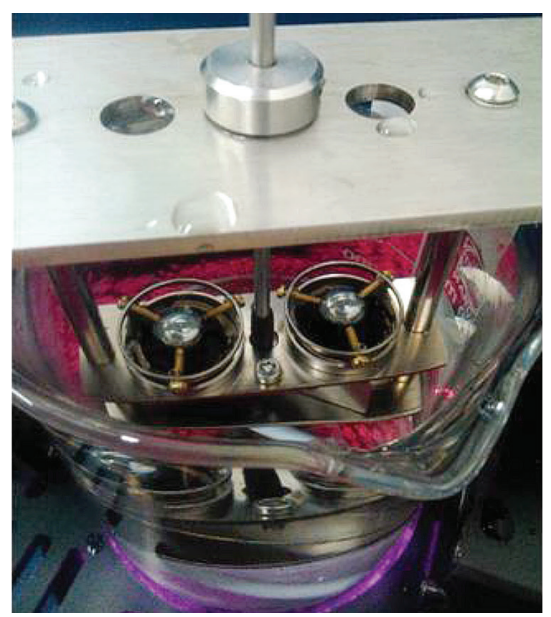

a) configuration of the laboratory test

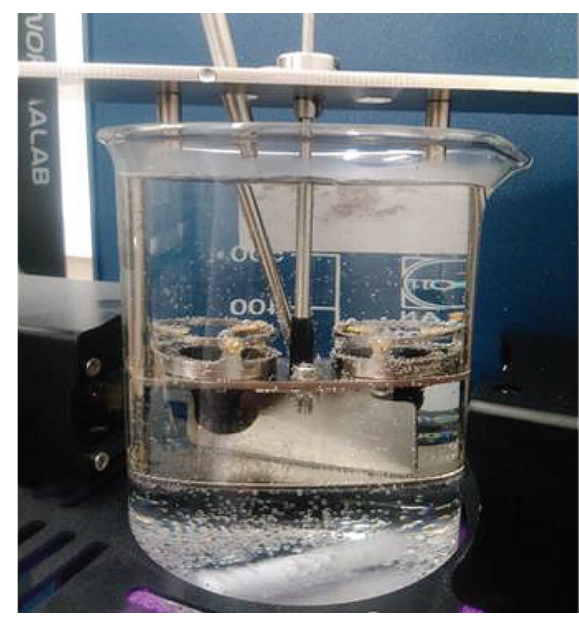

b) deformation of the binder from heating

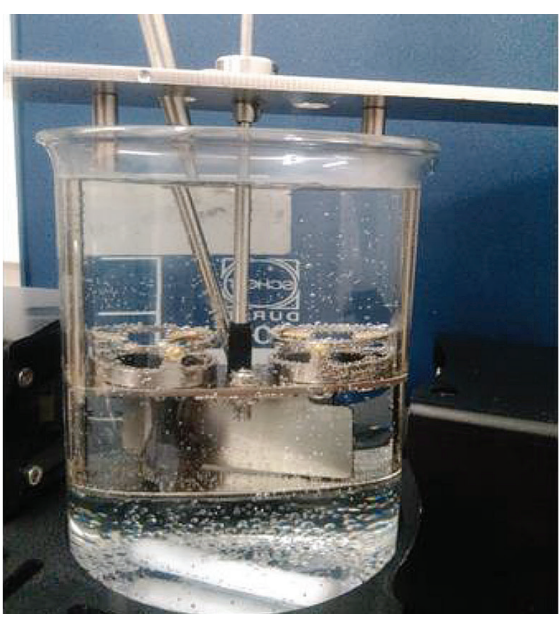

c) end of the test

Fig. 3 Softening point test according to STN EN 1427 


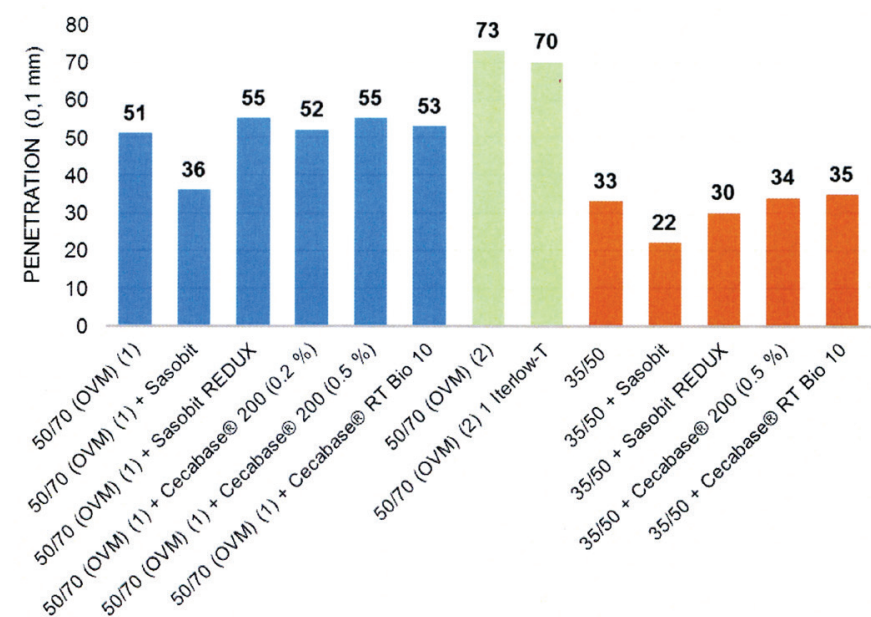

Fig. 4 Penetration $(0.1 \mathrm{~mm})$ of modified bitumen

The penetration results at $25^{\circ} \mathrm{C}$, and the softening point in Figures 4 and 5 point to the fact that Sasobit REDUX, Cecabase ${ }^{\circledR}, \mathrm{Ce}-$ cabase ${ }^{\circledR}$ RT Bio 10, and Iterlow-T have almost no effect on these characteristics. The penetration of the reference binders is at the penetration boundary defined by the standard: a binder 50/70 (OVM) (1) has pen $=51(0.1 \mathrm{~mm})$; a binder 50/70 (OMV) (2) has a pen value $=$ 73 , which is above this range. A binder $35 / 50$ with a pen value $=33$ $(0.1 \mathrm{~mm})$ is below the range. The penetration of the $50 / 70$ (OVM) (1) binder with the use of additives increased to a maximum of 55 $(0.1 \mathrm{~mm})$. The chemical additive caused a decrease in the penetration of about $4 \%$ at 50/70 (OVM) (2). At 35/50 with chemical additives, penetration increased only to a minimum of $35(0.1 \mathrm{~mm})$; the Sasobit REDUX additive resulted in a slight decrease of $30(0.1 \mathrm{~mm})$. The Sasobit caused a decrease in the penetration values of around $30 \%$ compared to the reference 50/70 (OMV) (1) binder. Similarly, the values of the softening point did not change; only the Sasobit caused an increase of about $20^{\circ} \mathrm{C}$. Considering the results of the penetration and softening point of the 57/70 (OMV) (1) binder modified by Sasobit, these values meet the requirements of the polymer modified binder $\mathrm{PmB} 45 / 70-65$, and the results of the 35/50 binder meet the requirements of the PmB 10 / 40-65 binder.

In addition to the effect of the additive on the behaviour of the binder, the graphs show the different quality of the 50/70 reference binders. In the case of the softening point values, there are no differences, although each temperature stage has, of course, an impact on the behaviour of the binder and consequently the mixture. Significant differences, however, are found in the penetration values, when the $50 / 70(\mathrm{OMV})(1)$ binder reaches a value of $51(0.1) \mathrm{mm}$, which is at the lower limit of the range, and when the 50/70 (OMV) (2) binder exceeds the upper limit of the range of 3 penetration units. It follows

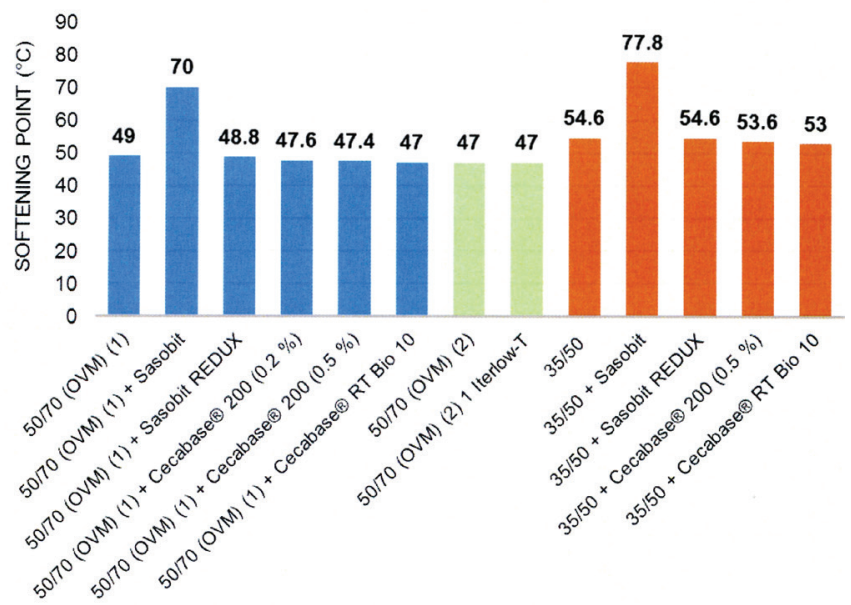

Fig. 5 Softening point $\left({ }^{\circ} \mathrm{C}\right)$ of modified bitumen

that even though we may have a binder from one producer, the same quality is not always guaranteed. This has also been confirmed within the context of the projects mentioned in Section 2. We had an opportunity to observe that a binder with the same grade delivered at a different time once had the penetration value at the upper limit and at other times at the lower limit of the range defined by the standards.

Partial results are presented in (Capayova, 2017) and (Capayova at.al., 2017).

It is important to verify also other properties of the binder modified by additives and then assess the effect of the additives on the properties of a mixture. As an example (Stefunkova, 2011), (Valentin at. al., 2013), the effect of the wax additive and the chemical additive on stiffness modulus and resistance to permanent deformations is shown in the Table 3. In general, higher stiffness modulus are achieved by using wax. Chemical additive caused an increase in stiffness of about $14 \%$ at a higher temperature of $27^{\circ} \mathrm{C}$. The mixes with wax had a higher resistance to permanent deformations in either cases; the chemical additive has increased the $\mathrm{PRD}_{\mathrm{AIR}}$ value by more than twice. For a comprehensive assessment of the impact of additives on the properties of binders and mixtures, a large set of laboratory tests needs to be evaluated in order to convey adequate conclusions.

\section{CONCLUSION}

In Slovakia, warm mix asphalt does not amount to even one percent of the total production of asphalt mixtures. A lot of warm mix asphalt additives are available, but the main criterion for selection is, in most cases, their cost. Despite the beneficial results of many research tasks, the use of these additives in Slovakia is not what it should be.

Tab. 3 Stiffness modulus and resistance to permanent deformation of selected mixtures

\begin{tabular}{|c|c|c|c|c|c|c|c|}
\hline \multirow{2}{*}{ Mixture } & \multicolumn{5}{|c|}{ Stiffness modulus (MPa) at temperature } & \multicolumn{2}{|c|}{$\begin{array}{c}\text { Resistance to permanent } \\
\text { deformation }\end{array}$} \\
\hline & $\mathbf{0}$ & 5 & 15 & 27 & 40 & PRD $_{\text {AIR }}(\%)$ & $\mathrm{WTS}_{\mathrm{AIR}}(\mathrm{mm})$ \\
\hline $\mathrm{AC} 11 \mathrm{O}+50 / 70$ & - & 14050 & 6500 & 1800 & - & 2,2 & 0,026 \\
\hline AC $11 \mathrm{O}+3 \%$ Sasobit & - & 13500 & 7150 & 2500 & - & 2 & 0,019 \\
\hline AC $11 \mathrm{O}+1 \%$ Iterlow- $\mathrm{T}$ & - & 11650 & 5850 & 2050 & - & 4,5 & 0,074 \\
\hline $\mathrm{AC} 22 \mathrm{P}+50 / 70$ & 21499 & - & 9318 & 3049 & 865 & 5,6 & 0,16 \\
\hline AC $22 \mathrm{P}+3 \%$ Sasobit & 22894 & - & 10978 & 3957 & 1167 & 2,8 & 0,07 \\
\hline
\end{tabular}


The results presented of the basic properties of the standard 35/50 and 50/70 bituminous binders confirmed the effect of Sasobit additive on the bitumen grade: a decrease in penetration of about $30 \%$ and an increase in the softening point of about $43 \%$ in both cases. Other additives, e.g., Sasobit REDUX, Iterlow-T, Cecabase ${ }^{\circledR} 200$, and Cecabase ${ }^{\circledR}$ Bio RT 10, had either no effect on the bitumen grade or their impact was minimal. It should be noted that these are the results of the basic properties of the binder, which in most cases meet the requirements of the standards. It is necessary to verify the other properties, such as any change in viscosity, the adhesion of the binder to the aggregates, the force ductility, and the elastic recovery. It is important to verify the effect of additives on the resistance of the binder to low temperatures by the Fraass breaking point test or bending stiffness determined by the Bending Beam Rheometer (BBR) test. It would also be interesting to observe the possible changes in the composition of the bitumen group. Subsequently, it is required to verify the properties of the asphalt mixture with binder modified by additives and compare them with the properties of the standard hot mix asphalt. It is necessary to focus not only on the traditional empirical tests but also on the performance based properties of the mixture. In addition to assessment of the fatigue properties and resistance to permanent deformations, it is also important to assess the suitability of the combination with rejuvenators, recycled material, and other additives.

The paper was created with the support of the VEGA projects No. 1/0501/17 Environmentally acceptable materials and technologies for traffic areas and the ITMS project No.: 26240220084 - University Science Park Slovak University of Technology in Bratislava 


\section{REFERENCES}

European Commission (2016) Statistical Pocketbook 2016, EU Transport in Figures, Luxembourg: Publications Office of the European Union, 2016, online pdf document available on https:/europa.eu, ISBN 978-92-79-51527-9, ISSN 2363-2739, doi:10.2832/809634 MI-AA-16-001-EN-N.

Capayova, S. (2017) Vplyv prísad Sasobit a Cecabase na vlastnosti asfaltového spojiva. (Effect of Sasobit and Cecabase on the Properties of Bitumen binders) In: conference on Asphalt Pavements 2017, 28-29 Nov. 2017, Ceske Budejovice, Czech Republic, PRAGOPROJEKT, a.s., SVS department proceedings. 1. ed. Prague: USB key, 7 pp. , ISBN 978-80-906809-0-6.

Capayova, S., Zuzulova, A., Bacova, K. (2015) Properties of asphalt mixtures with reclaimed material in Slovakia. In: Green Building, Materials and Civil Engineering: selected papers from the 4th International Conference on Green Building, Materials and Civil Engineering (GBMCE), Hong Kong, China, 21. - 22. 8. 2014. 1st ed. London: CRC Press, Taylor \& Francis Group, 2015, pp. 17-20. ISBN 978-1-138-02669-8. SCOPUS Code 123669.

Capayova S., Zuzulova A., Hodakova D., Schlosser T. (2017) Influence of Chemical Additives on Bitumen Binder Properties. In: Proceedings of the $17^{\text {th }}$ SGEM 2017 International multidisciplinary scientific geoconference, Conference proceedings Vol. 17, Energy and Clean Technologies No. 41, STEF92 Technology Ltd., Sofia, Bulgaria, 2017, ISBN 978-619-7408-06-5, ISSN 1314-2704, DOI:10.5593/sgem2017/41, pp. 487-494.

Hamzah, M. O., Kakar, M. R., Quadri, S. A., Valentin, J. (2014) Quantification of moisture sensitivity of warm mix asphalt using image analysis technique, In: Journal of Cleaner Production, Vol. 68, Apr. 2014, pp. 200-208, DOI: 10.1016/j.jclepro.2013.12.072, WOS:000335114600023, ISSN: 0959-6526, eISSN: 1879-1786.

Remisova, E., Zatkalikova, V., Schlosser, F. (2016) Study of rheological properties of bituminous binders in middle and high temperatures, In: Civil and Environmental Engineering, Vol. 12, No. 1, May 2016, pp. 13-20, DOI: 10.1515/cee-2016-0002, WOS:000408221600002, ISSN: 1336-5835, eISSN: 2199-6512.
Stefunkova, S. (2011) Stanovenie kvalitativnych parametrov konštrukčných vrstiev z opätovne použitých materiálov (Determination of the Qualitative Parameters of Structural Layers from Reused Materials). Dissertation thesis. Bratislava Slovakia: Faculty of Civil Engineering, Slovak University of Technology in Bratislava, 2011. 93 pp.

Valentin, J., Mondschein, P., Beneš, J., Kasek, L., Soukupova, L. (2014) Impact of selected chemical additives on performance behavior of warm asphalt concrete mix. In: 3rd International Conference on Road and Rail Infrastructure (CETRA), Split, Croatia, Apr. 28-30, 2014, book series: Road and Rail Infrastructure, pp. 409-418, WOS:000372900600052, ISSN: 1848-9850.

Valentova, T., Altman, J., Valentin, J. (2016) Impact of asphalt ageing on the activity of adhesion promoters and the moisture susceptibility, In: 6th Transport Research Arena TRA2016, Book Series: Transportation Research Procedia, Vol. 14, Warsaw, Poland, Apr. 18-21, 2016, pp. 768-777, 2016, DOI: 10.1016/j.trpro.2016.05.066, WOS:000383251000082, ISSN: 2352-1465.

Valentin, J., Beneš J., Soukupová, L., Moral, X., Cápayová, S. (2013) Posouzení experimentálně vyrobených a prümyslově vyvijených alternativ nizkoviskózních asfaltových pojiv - charakteristiky asfaltových pojiv, charakteristiky směsi ACO 11+ (Assessment of experimentally produced and industrially developed alternatives of low-viscosity bituminous binders - characteristics of asphalt binders, characteristics of the ACO 11+ mixture). Research report 1.1.5, Centrum CESTI, Faculty of Civil Engineering, CTU in Prague, Czech Republic, 2013, 15 pp. (in Czech).

STN EN 1426 (2016) Bitumen and bituminous binders. Determination of needle penetration, Slovak Office of Standards, (in Slovak).

STN EN 1427 (2016) Bitumen and bituminous binders. Determination of the softening point. Ring and Ball method, Slovak Office of Standards, (in Slovak). 